\title{
SWINGS AND ROUNDABOUTS: EVALUATING THE CHILDREN, YOUNG PERSONS, AND THEIR FAMILIES (YOUTH COURTS JURISDICTION AND ORDERS) AMENDMENT ACT 2010, S 14
}

Hannah Wilson*

The Children, Young Persons, and Their Families (Youth Courts Jurisdiction and Orders) Amendment Act 2010, which came into effect on 1 October 2010, could be considered the most significant change to the Children, Young Persons, and Their Families Act since its introduction in 1989. The new Act has two main functions: it extends the jurisdiction of the Youth Court and gives the Court a new range of orders. This paper analyses $s 14$ of the new Act which extends the jurisdiction to 12 and 13 year old serious and recidivist offenders. The paper assesses what problem Parliament was trying to address with this amendment. It argues that the change in jurisdiction could be said to be motivated by populist politics rather than addressing a known change in child offending. The paper then explores how s 14 changes the underlying assumptions about the level of responsibility we attribute to children. It then recommends that serious and recidivist offenders continue to be dealt with by the Family Court. The paper acknowledges, however, that changes could be made to strengthen the Family Court's existing powers to ensure children are dealt with more effectively.

\section{INTRODUCTION}

The Children, Young Persons and Their Families (Youth Courts Jurisdiction and Orders) Amendment Act 2010 (the new Act) came into effect on 1 October 2010. The new Act is the most significant change to the Children, Young Persons and Their Families Act (CYPF Act) since its

Submitted as part of the LLB(Hons) programme at Victoria University of Wellington. I would like to acknowledge the assistance of my supervisor Dr Nessa Lynch. 
introduction in 1989. The most important feature of the new Act is the extension of the jurisdiction of the Youth Court to include 12 and 13 year old serious and recidivist offenders. ${ }^{1}$ This paper will assess this extension, as set out in s 14 , and its likely effect. This is done by addressing three overarching questions. The first of these questions is whether serious offending by 12 and 13 year olds is a problem. It is argued that Parliament failed to demonstrate any change in offending by 12 and 13 year olds or sufficiently articulate a problem with the status quo which would necessitate a change in jurisdiction.

Secondly, assuming there is a problem to be addressed; was the extended jurisdiction of s 14 the best way to address this problem? The thesis of this paper is that $\mathrm{s} 14$ is not the appropriate policy option. This is due to two criticisms of s 14: the arbitrary nature of the shifting jurisdiction and the implicit change in the way child offenders must be viewed and treated. First, the movement of 12 and 13 year old serious and recidivist offenders to the Youth Court is wholly arbitrary; the movement is based on the gravity of the offence determined by the maximum penalty that offence may carry. This seems contrary to the principle that the criminal law should intervene only where necessary. Parliament could have extended the jurisdiction by listing specific offences which trigger the extended jurisdiction or by making the extension discretionary. Moreover, extending the jurisdiction of the Youth Court to certain 12 and 13 year old children implicitly changes the way we view and treat these children. The reason New Zealand has separate Family and Youth Courts is because we have determined that children and young people are inherently different. For the Family Court, the interests of the child are of paramount importance. ${ }^{2}$ This principle does not apply to children who appear in the Youth Court, where the interests of the public are given more weight. Thirdly, if s 14 is an inadequate means of dealing with the problem, what would have been an appropriate solution? This paper argues that, before changing the jurisdiction of the Youth Court, Parliament should have first addressed inadequacies with the status quo. Several recommendations are made which could ensure the Family Court is better able to address serious and recidivist child offenders.

\section{A Overview of the Youth Justice System in New Zealand}

The CYPF Act governs the process for dealing with both children and young people who commit offences. This paper looks at the way New Zealand has chosen to deal with offenders between the ages of 10 and $17 .{ }^{3}$ New Zealand has a split court system, whereby children (10-13 year olds) are treated differently from young people (14-17 year olds). ${ }^{4}$ This paper observes this

1 Children, Young Persons, and Their Families (Youth Courts Jurisdiction and Orders) Amendment Act 2010, s 6.

2 Ibid.

3 Crimes Act 1961, s20.

4 Children, Young Persons, and Their Families Act 1989, s 2(1). 
distinction when using the terms 'children' and 'young people'. The effect, in distinguishing between children and young people, is that New Zealand has two zones of transition..$^{5}$ The Family Court has jurisdiction over children, while the Youth Court has jurisdiction over young people, and beyond 17 years offenders are subject to the adult court process. The Family Court and the Youth Court operate under different guiding principles and have a different range of orders available to them. Age at commission of an offence is significant because it determines the kinds of orders made against the child or young person and the principles underpinning these orders.

The main objective of the CYPF Act is to promote the wellbeing of children, young people and their families. ${ }^{6}$ This objective is achieved through principles which underpin the operation of the CYPF Act. The CYPF Act first sets out general principles which apply to both the Family and Youth Courts. These principles encourage involvement of family, whanau and iwi and seek to maintain and strengthen family relationships. ${ }^{7}$ Consideration is given to the welfare of the child or young person and the stability of the wider family. ${ }^{8}$ Consideration is also given to the wishes of the child or young person and orders are made in an appropriate timeframe. ${ }^{9}$ The CYPF Act also states that "the welfare and interests of the child or young person shall be the first and paramount consideration having regard to the principles set out in ss 5 and $13 " .{ }^{10}$ However, this last principle does not apply to the parts of the CYPF Act governing the Youth Court.

The Youth Court has a separate set of principles. Unless the public interest requires, criminal proceedings should not be brought against young offenders. ${ }^{11}$ When criminal proceedings are warranted the offender, so far as is possible, will be kept in the community. ${ }^{12}$ Criminal proceedings should not be instituted in order to provide for the welfare of the youth. ${ }^{13}$ Age is a mitigating factor when deciding on a sanction; sanctions imposed should be the least restrictive and the most likely to

5 B Whyte Youth Justice in Practice: Making a Difference (The Policy Press, University of Bristol, 2009) at 3.

6 Children Young Persons, and Their Families Act 1989, s 4; see also G Maxwell and A Morris "Youth Justice in New Zealand: Restorative Justice in Practice?" (2006) 62 Journal of Social Issues 239 at 242.

7 Children, Young Persons, and Their Families Act 1989, subss 5(a) and (b).

8 Ibid, s 5(c).

9 Ibid, s 5(f).

10 Ibid, s 6.

11 Ibid, s 208(a).

12 Ibid, s 208 (e)

13 Ibid, s 208(b). 
maintain the development of the child or young person within their family. ${ }^{14}$ Unlike the Family Court the Youth Court must have due regard for the interests of the victim. ${ }^{15}$

These principles are manifest in the different orders available to the Family and Youth Courts. For both courts, minimal intervention is preferred because early introduction into the welfare or justice system increases the likelihood of recidivism. ${ }^{16}$ This means children and young people are warned by the Police or diverted through the Police Youth Aid Alternative Action scheme for most offences and criminal charges are not pursued. ${ }^{17}$

A child, beyond a warning or diversion, can be referred to a Family Group Conference (FGC). A FGC is an informal meeting of the offender, their family and the victim. ${ }^{18}$ The focus is not on the offending but on the wider circumstances enabling the offending, specifically the child's home environment. Children are not required to accept criminal responsibility but they must be held accountable for their offending. ${ }^{19}$ This accountability might include the child writing an apology or making reparation to the victim. Subsequent to a FGC, the child may be referred to the Family Court, where the Court can make a declaration that the child is in need of care and protection dependant on the frequency, nature and magnitude of offending. ${ }^{20}$

The Youth Court's principles are based on the Justice Model. ${ }^{21}$ The Justice Model holds that most offending by young people is an inevitable by-product of growing up. ${ }^{22}$ This is encapsulated in the principle that young offenders are held accountable for offences which they commit, but are dealt with in an appropriate manner. ${ }^{23}$ Young people are required to accept responsibility for their offending, but with a focus on restorative justice. ${ }^{24}$ Beyond diversion, young people can be referred

14 Ibid, s 208(f)

15 Ibid, s 208(g).

16 J Cameron, J Guest and R Ludbrook Brookers Family Precedents (online looseleaf ed, Brookers).

17 N Lynch "A Change in the Law for Child Offenders: The Children, Young Persons, and Their Families (Youth Courts Jurisdiction and Orders) Amendment Act 2010" (2010) 6 NZFLJ 289 at 289.

18 A Family Group Conference must include the child plus at least one family member, a Care and Protection Coordinator (Children, Young Persons, and Their Families Act 1989, Part 2) or Youth Justice Coordinator (Children, Young Persons, and Their Families Act 1989, Part 4).

19 P Boshier, J Moore and S Hale Child Offenders Manual: A Practical Guide to Successful Intervention with Child Offenders (3rd ed, Chief Judges Chambers, Wellington, 2002) at 4.

20 Children, Young Persons, and Their Families Act 1989, s 14(1)(e).

21 J Cameron, J Guest and R Ludbrook, above n 16, at [NT1.1.06].

22 Ibid.

23 Children, Young Persons and Their Families Act 1989, s 4(f).

24 P Boshier, J Moore and S Hale, above n 19, at 4. 
to a Youth Justice Conference for an 'intention to charge' FGC. Alternatively, the young person can be arrested and have charges laid against them.

\section{B Overview of the Children, Young Persons and Their Families (Youth Court Jurisdiction and Orders) Amendment Act 2010}

The new Act marks the most fundamental change to the youth justice system since 1989, because of the changes it makes to the jurisdiction and orders available to the Youth Court. ${ }^{25}$ The overarching purpose of the new Act is to "strengthen the response to seriously offending children and young people." 26 Although this paper focuses on the extended jurisdiction, it is important to understand the wider context of the new Act. The Select Committee summarised the changes under five headings: wider Youth Court jurisdiction; breaching, varying and cancelling orders; residential programmes; judicial monitoring; and intensive supervision orders. ${ }^{27}$

Provisions relating to breaching, varying and cancelling orders brought in stricter consequences for young people who do not comply with court orders, as well as parents who fail to comply with parenting education orders. ${ }^{28}$ Residential programmes give the Youth Court more options for dealing with young offenders. ${ }^{29}$ The new Act was reported in the media as the 'boot camp Bill' because proposed residential programmes included physical army-style programmes. ${ }^{30}$ Residential orders can now be made for up to six months, as opposed to the previous three month maximum. New kinds of orders can also be made: parents and young people can be required to attend parenting programmes, ${ }^{31}$ and young people can be obliged to attend mentoring programmes and alcohol and drug rehabilitation programmes for up to 12 months. ${ }^{32}$ Intensive supervision orders, up to 12 months, are available for young people who fail to comply with other orders and can result in judicial monitoring. ${ }^{33}$ Judicial monitoring includes the wearing of ankle bracelets for recently released young offenders. On the whole, the new Act is a move away from the current CYPF Act

25 Youth Court of New Zealand "Submission to Social Services Select Committee on the Children, Young Persons, and Their Families (Youth Courts Jurisdiction and Orders) Amendment Bill 2009" at 5.

26 Children, Young Persons, and Their Families (Youth Courts Jurisdiction and Orders) Amendment Bill 2009 (16-2) at 2.

27 Ibid.

28 Children Young Persons, and Their Families Act 1989, s 30.

29 Children, Young Persons, and Their Families (Youth Courts Jurisdiction and Orders) Amendment Act 2010, s 31 .

30 P Gower "Tough Justice for the Young" The New Zealand Herald (New Zealand, 17 February 2009) at A01.

31 Children, Young Persons, and their Families Act 1989, s 283(ja).

32 Ibid, ss 283(jc) and 283(jb).

33 Ibid, s 296(g). 
principles because it introduces a more punitive arsenal of orders for dealing with children and young people.

\section{THE PURPOSE OF EXTENDING THE JURISDICTION OF THE YOUTH COURT}

This section addresses question one: is there a 'problem' which necessitates a change to the status quo? The political discourse in the lead up to the new Act is examined to discern Parliament's 'problem definition'.

\section{A Determining Parliament's Purpose}

The National party's 2008 election campaign signalled youth offending as an area of focus. In John Key's A Fresh Start for New Zealand speech, these offenders were targeted because of an increase in offending: "Violent youth crime is at an all-time high. Robbery is up. Grievous assaults are up. Aggravated robbery is up." ${ }^{34}$ In 2008, violent offending by young people was above average with 198 apprehensions in $10,000 .{ }^{35}$ Over the period 1995 to 2008 there has been an upwards trend in the number of apprehensions for violent offending by young people, although the number of apprehensions for robbery declined in 2008 to 8 per 10,000, down from a high of 11 in $2007 .{ }^{36}$ However, this speech targeted offending by young people and did not identify an increase in offending by children. Although in 2008 the number of violent offences was slightly above average, the Ministry of Justice states that for the period 1995-2008 the overall rate of violent offences by children remained static. ${ }^{37}$ It is clear from the data given, that young people are being targeted in this speech and the legislation on the whole, not child offenders, who are the ones ultimately affected by s 14 .

The speech then goes on to single out 12 and 13 year old offenders who may be convicted of serious crimes, saying they "can only be dealt with by the Family Court" and cannot benefit from the "wider range of powers" available to the Youth Court. ${ }^{38}$ However, it was not made clear why the powers of the Family Court were considered inadequate, nor was any evidence presented to demonstrate the Youth Court's orders could provide a better means of deterrence for serious child offenders. The speech also identifies recidivist offending as a problem, stating that "young criminals

\footnotetext{
34 John Key "A Fresh Start for New Zealand: A State of the Nation Speech" (29 January 2008).

35 Ministry of Justice Child and Youth Offending Statistics in New Zealand: 1992 to 2008 (Ministry of Justice, Wellington, 2010) at 36.

36 Ibid.

37 Ibid, at 34.

38 John Key, above n 34 [emphasis added].
} 
are graduating from petty crime to more serious crime; unexploded time-bombs on a fast track to Paremoremo". ${ }^{39}$ It is not clear how extending the jurisdiction will address recidivist offending.

In Parliament Paula Bennett, the Minister for Social Development, reiterated the Government's overall purpose of reducing "violent, serious, and repeat offending". ${ }^{40}$ Most of her speech at the First Reading focused on the 'Fresh Start' initiatives, the new orders available to the Youth Court. However, the speech also mentioned the "need to intervene at the earliest opportunity to safeguard our communities, to do what we can to break the crime cycle". This seems to refer to 12 and 13 year olds who will be subject to the Youth Court's jurisdiction. Ms Bennett acknowledged the possibility of exacerbating the problems facing young people through interaction with the justice system, but stated the wider range of Youth Court orders would help ameliorate that. ${ }^{41}$ However, as with $\mathrm{Mr}$ Key's speech, it was unclear why the Family Court's orders were considered inadequate for some children and how the Youth Court would be more effective. Ms Bennett identified a group of 1,000 serious young offenders, between the ages of 12 and 16, which the new Act would affect. ${ }^{42}$ It was not made clear what constituted a serious young offender or what portion of these offenders were children brought under s 14. This figure was revised in the Committee of the Whole House, where it was stated that around 40 child offenders would be affected. ${ }^{43}$ It was not until the Committee stage, when the Bill was in its final form, that Ms Bennett articulated what constituted a serious offence. She cited serious repeat burglary, arson, aggravated robbery and rape as serious offences. ${ }^{44}$ She also addressed the fact that the Bill was intended to give greater powers to the Youth Court in order for Judges to have greater discretion about the orders they make. ${ }^{45}$ One strength of the Bill, she thought, was that it gave discretion to the Youth Court to remit children to the Family Court if they thought they were in need of care and protection.

\title{
B Problem Definition
}

This paper takes the view that legislation should always have as its objective the solution of some known problem, the symptoms of which it is trying to rectify. ${ }^{46}$ At the Committee stage, the

\author{
39 Ibid. \\ 40 (18 February 2009) 652 NZPD 1440. \\ 41 (16 February 2009) 660 NZPD 9003. \\ 42 (18 February 2009) 652 NZPD 1440. \\ 43 (16 February 2010) 660 NZPD 9003 \\ 44 Ibid, at 9002. \\ 45 Ibid, at 9003. \\ 46 K Baehler "In Praise of 'Irrational' Drug Policy" (2000) Public Sector 23(3) at 2.
}


opposition challenged a lack of problem definition from the Government. Lianne Dalziel directly addressed the lack of problem definition, stating: ${ }^{47}$

It does not make sense that a child who is not old enough to babysit is actually now old enough to face the consequences that would be faced by a young person ... the Committee needs to have some understanding as to what the Government is trying to achieve.

Jacinda Arden also queried the lack of statistics on the extent of child offending, asking "if we cannot even quantify the number of children who would be affected by it, why are we making it [the change to jurisdiction]?"48

Those criticisms aside, from the above, it would seem that the Government was trying to address a problem with dual aspects with s 14. The problem can be defined as: Serious and recidivist 12 and 13 year old offenders have become a problem and they are not adequately dealt with by the Family Court. The first aspect is that serious and recidivist child offenders are a problem and both serious crime and recidivism can be avoided by early intervention. Secondly, that the Youth Court is best placed to address the problems of 12 and 13 year old serious and recidivist offenders because of the range of orders the Youth Court can make. While it was never made explicit that the operation of the Family Court was a problem, this is the implication of s 14 . The validity of this dualistic problem will now be evaluated.

\section{The Extent of Serious Offending by 12 and 13 Year Olds}

The overall apprehension rate for both children and young people has declined over the 19952008 period. ${ }^{49}$ An apprehension is recorded whenever a child or young person has been dealt with by Police, not when an arrest is made. ${ }^{50}$ The most common offences committed by children and young people are property offences; making up 69 per cent of child offending and 61 per cent of offending by young people in $2008 .{ }^{51}$ Overall, 10-13 year olds have the lowest apprehension rate in all categories of offending, except property. As mentioned above, apprehensions for violent crimes committed by children have remained static between 1995 and 2008.

In the media and in the House, the number of children affected by the new Act was never made clear. One reason for the vagary is that the distinction between young people and children is not always correctly observed; the two groups are talked about synonymously. Another reason is that statistics record all apprehensions, not the number of individual offenders. It is not clear how many

47 (16 February 2010) 660 NZPD 8945.

48 Ibid, at 9007.

49 Ministry of Justice, above n 35, at 32.

50 Ibid, at 15 .

51 Ibid. 
of these apprehensions are repeat child offenders. Yet another problem in this area remains a lack of data on the offending of children and their involvement in the criminal justice system. ${ }^{52}$ This is partly because the Family Court does not charge children with an offence, so there are no longitudinal statistics on recurrent appearances at FGCs or the Court. When data is given for children it is recorded for the 10-13 year age bracket and the data is not further broken down into year groups. Given the fact the data is not broken down further, it is unclear why the jurisdiction of the Youth Court was not extended to all child offenders. It would be less arbitrary to lower the age for all children, rather than just 12 and 13 year olds.

There has been no change in child offending which alone could have prompted a review of the Youth Court's jurisdiction. Additionally, there is no reason why only 12 and 13 year olds have been identified. This is not to say that offending by children is not a concern, especially those children who are recidivist offenders. The issue this paper has with the problem definition is that these children are not actually identified.

\section{The Problem with Family Court Orders}

This new Act is about giving new powers to the Youth Court. The Government assumed that, given new orders were the best way to address offending by young people, they would be an effective way to address serious and recidivist offending by children. However, it was never made clear why the powers of the Family Court were ineffective. New Zealand has opted to have separate Family and Youth Courts to specifically address the needs of children. In 2002 the Law Commission reaffirmed the benefit of having separate Youth and Family Courts and did not favour collapsing the two into one Court. ${ }^{53}$ Given the key principle of the CYPF Act is the well-being of the child it is unclear why orders the Family Court can make, which are directed at the well-being of the children, are considered ineffective.

\section{Popular Agenda Setting}

It seems that the primary purpose of the new Act was to deliver a new range of orders to the Youth Court to manage offending by young people. These orders could be justified on the basis that apprehensions for violent crime by young people have increased. They could also be justified on the basis that these new orders would be beneficial for young people. A number of select committee submissions applauded the introduction of the new orders. ${ }^{54}$ However, the same submissions denounced the extended jurisdiction for children. ${ }^{55}$

52 Statistics New Zealand Review of Crime and Criminal Justice Statistics Report 2009 (Statistics New Zealand, Wellington, 2009).

53 Law Commission Delivering Justice for All: A Vision for New Zealand Courts and Tribunals (NZLC R85, $2004)$ at 209.

54 See for example: Youth Horizons "Submission on the: Children, Young Persons and Their Families (Youth Courts Jurisdiction and Orders) Amendment Bill 2009" at 7; Human Rights Commission "Submission on 
It could be argued that children were only included in the new Act to pander to populist politics. Populist politics essentially pits a virtuous and homogeneous majority against a set of elites or dangerous 'others' who are together depicted as depriving (or attempting to deprive) the majority of their rights, values, prosperity, identity and voice ${ }^{56}$ It is politics which appeals to the unity of the masses. ${ }^{57}$ This was the argument raised by opposition Member of Parliament, Annette King, who argued: 58

[This Bill] is not about trying to improve the lives of young people and turn their lives around. It is populist politics. It was about announcing something called 'boot camps' before the election.

Youth Justice formed a central plank of the National Party's 2008 election campaign and was one of the Government's '100 days' policies which saw the Government achieve 27 policy changes within the first 100 days in Office. ${ }^{59}$ At the first reading, the Bill was passed in urgency. It is assumed that the only reason for the use of urgency was to ensure that it was passed within the 'first hundred days'. The use of urgency seems derived from purely political motives.

Judge Becroft, Principal Judge of the Youth Court, identified a lack of detailed statistics about youth offending in New Zealand as one key problem contributing to a climate of fear about youth offending. As Cunneen and White argue "empirical evidence and calls for reasoned debate on youth justice are lost when populist politics are in control". 60 The media reports increasing crime rates, when rates remain constant. This fuels the perception that current youth justice systems are ineffective. Jo Goodhew's speech at the first reading of the Bill said: ${ }^{61}$

The public of NZ have told us that they fear for our young people. They fear for young offenders, they fear that the current system is not supporting those young offenders to not continue down their

the Children, Young Persons and Their Families (Youth Courts Jurisdiction and Orders) Amendment Bill" at 3; New Zealand Law Society "Submission on the: Children, Young Persons and Their Families (Youth Courts Jurisdiction and Orders) Amendment Bill 2009" at 1.

55 See for example: Youth Horizons, ibid, at 11; Human Rights Commission, ibid, at 3; New Zealand Law Society, ibid, at 1.

56 Daniele Albertazzi and Duncan McDonnell Twenty-First Century Populism: The Spectre of Western European Democracy (Palgrave Macmillan, New York, 2008) at 3.

57 Craig Calhoun (ed) Dictionary of Social Sciences (Oxford University Press, New York, 2002) at 373.

59 "John Key's First 100 Days" Sunday Star Times (7 March 2009) <www.stuff.co.nz>.

60 C Cunneen and R White Juvenile Justice: Youth and Crime in Australia (3rd ed, Oxford University Press, Melbourne, 2007) at 82.

61 (18 February 2009) 652 NZPD 1440 [emphasis added]. 
offending track, and that we do not acknowledge the seriousness of the situations of some of the 12 and

13 year old offender.

Preying on this fear means that government can give the public the impression that it is a 'strong' policy setter by 'cracking down' on crime, through more punitive measures.

The new Act is similar in language to changes introduced in the United Kingdom in 2002; even the name Intensive Supervision Orders is taken from the United Kingdom programme. ${ }^{62}$ In the United Kingdom these orders have been considered a move toward more punitive sanctions. Hollingsworth argues that before the courts children's rights hold sway, while at a policy level the dialogue is about children's responsibility. ${ }^{63}$ In Tolmie and Brookbanks' chapter "Recurring themes in Contemporary Criminal Justice Developments and Debates" it is argued that there has been a move away from quality to quantity with regard to legislative attitudes towards youth offending in New Zealand. ${ }^{64}$ Playing to populist politics can result in a policy which is dictated by populist ideals and not conscientious policy making.

\section{LIKELY EFFECT OF S 14}

The accuracy of the underlying problem definition aside, this paper now examines how the purpose and problem definition have ultimately been translated into legislation.

\section{A Overview of $s 14$}

There are three instances where the Youth Court may have jurisdiction over children. The first instance remains unchanged in the new Act: ${ }^{65}$

(a) Where the child is of or over the age of 10 years, and the offence is murder or manslaughter:

The age of criminal responsibility in New Zealand is 10 years for the offences of murder and manslaughter. ${ }^{66}$ However, the new Act extends the scope of the criminal law to 12 and 13 year olds who commit offences other than murder or manslaughter. The second instance is: ${ }^{67}$

62 Audit Commission Youth Justice 2004: A Review of the Reformed Youth Justice System (Belmont Press, London, 2004) at 4.

63 K Hollingsworth "Responsibility and Rights: Children and their Parents in the Youth Justice System" (2007) 21 Int J Law \& Fam 190 at 190.

$64 \mathrm{~J}$ Tolmie and W Brookbanks "Recurring Themes in Contemporary Criminal Justice Developments and Debates" in J Tolmie and W Brookbanks Criminal Justice in New Zealand (LexisNexis, Wellington, 2007).

65 Children, Young Persons, and Their Families (Youth Courts Jurisdiction and Orders) Amendment Act 2010, s 14(1)(a).

66 Crimes Act 1961. s 61. 
(b) Where the child is aged 12 or 13 years, and the offence is one (other than murder or manslaughter) for which the maximum penalty available is or includes imprisonment for life or for at least 14 years:

Serious offenders are targeted by extending the jurisdiction in any instance where a child has committed a serious offence; a serious offence being an offence carrying a penalty of 14 years or more. The third instance is: ${ }^{68}$

(c) Where the child is aged 12 or 13 years and is a previous offender under subs (1A) or (1B), and the offence is one (other than murder or manslaughter) for which the maximum penalty available is or includes imprisonment for at least 10 years but less than 14 years.

The third instance applies a definition of 'previous offender'. A previous offender is a child who has had a previous order made against them in the Family Court ${ }^{69}$ or the High Court ${ }^{70}$ and the previous offence carries a penalty of 10 years but less than 14 years.

It is worth noting that a Youth Court Judge has the power to remit a case back to the informant usually the Police - if they think the child would be best dealt with through a Care and Protection order. ${ }^{71}$ Having outlined the nature of the section, the paper now examines two specific aspects of the section: the definition of serious offender and the definition of previous offender.

\section{B Serious Offender}

A 'serious offence' is defined according to the maximum penalty for that offence. For first time offenders and those who do not trigger the previous offender definition, a serious offence is one which carries a maximum penalty of 14 years. There are 32 offences which could apply to 12 and 13 year old first time offenders, including treason, ${ }^{72}$ piracy ${ }^{73}$ and slavery. ${ }^{74}$ More specifically affecting children will be property offences such as aggravated burglary ${ }^{75}$ and aggravated robbery. ${ }^{76}$ This provision can be illustrated using a hypothetical fact scenario.

67 Children, Young Persons, and Their Families (Youth Courts Jurisdiction and Orders) Amendment Act 2010, s $14(1)(b)$.

68 Ibid, s 14(1)(c)

69 Ibid, s 14(1A).

70 Ibid, s 14(1B).

71 Nessa Lynch "A Change in the Law for Child Offenders", above n 17, at 290.

72 Crimes Act 1961, s 73.

73 Ibid, s 92.

74 Ibid. See Appendix One for the full list of offences.

75 Crimes Act 196,1 s 232. 


\section{Scenario One:}

Manu is a 12 year old boy, of Maori descent. ${ }^{77}$ He comes from a low income, solo parent family. He has been exposed to alcohol and drug abuse in his household. ${ }^{78}$ Manu is with a group of young people from the neighbourhood. The people across the road have bought a new television and it is suggested that they break into the house and steal it. One of the young people takes a baseball bat, just in case. Manu goes along with them. They break into the property and find no one home. As they are taking the television out of the property a police patrol car sees the group and Manu is charged as party to an aggravated burglary. ${ }^{79}$

In reality it is quite likely the Police would take into account Manu's age and situation and decide to divert Manu through Police Youth Aid. However, if this was not the case, and the Police decided to pursue the charge, then it must be heard by the Youth Court because the 'serious offender' definition has been triggered. This seems a harsh penalty for several reasons. First, Manu is a party to the offence, not the main offender. Secondly, the 'serious offender' definition does not make allowance for children with no previous offending history. And finally, the change in jurisdiction can be made without reference to the child's family situation or the environmental factors contributing to his offending.

A more general criticism of both the serious and previous offender definitions is the arbitrary nature of defining offences according to a time period. This will include offences which will simply not be committed by children, making the provision too wide. It can be argued that if no children will commit these offences then there can be no harm caused, however, this is contrary to the theory of least possible intervention. ${ }^{80}$ As a general rule, we should not be extending criminal liability beyond that which is necessary. This is especially so where liability is extended to children. Section 14 could have been enacted with an explicit list of relevant offences, rather than all offences over 14 years. Similar changes were introduced in Ireland in $2006 .{ }^{81}$ Prior to 2006,10 year olds could be charged with murder or manslaughter. The amendment extended the list of offences for 10 year olds

76 Ibid, s 235.

77 A child offender is most likely to be a male and children of Maori ethnicity have an apprehension rate five times that of Pacific or NZ European Children. See Ministry of Justice, above n 35, at 41.

7848 per cent of child offenders have a history (or a family member had a history) of drug or alcohol abuse. See G Maxwell and J Robertson Child Offenders (Office of the Commission for Children, Wellington, 1995).

79 Crimes Act 1961, s 232.

80 Ulla Bondeson Alternatives to imprisonment: intentions and reality (Transaction Publishers, New Brunswick, 2002) at 212.

81 Criminal Justice Act 2006 (Ireland). 
to include rape and aggravated sexual assault. ${ }^{82}$ If the New Zealand Government wanted to target certain serious offences committed by 12 and 13 year olds, it could have listed these offences. For example, s 14 could extend the jurisdiction of the Youth Court for serious assault, burglary, arson, armed robbery, rape, and attempted murder, which were offences cited by the Prime Minister and the Minister for Social Devlopment in Parliament.

\section{Previous Offender}

The new Act extends the jurisdiction to previous offenders. If a child is a previous offender, then a lower threshold of offence is required before they are subject to the jurisdiction of the Youth Court. For these children, an offence where the "maximum penalty available is or includes imprisonment for at least 10 years but less than 14 years" will be sufficient to extend the jurisdiction. Under this section, there are 27 crimes which would apply to 'previous offenders' but would not apply to first time offenders. These include offences such as inciting mutiny ${ }^{83}$ and counterfeiting government seals, ${ }^{84}$ as well as more common offences, such as burglary. ${ }^{85}$

As first introduced, the Bill found two ways in which a young person could be a previous offender. First, a child could be a previous offender if they have been deemed to be in need of care and protection by the Family Court, after committing an offence with a minimum sentence of 10 years. Secondly, a child would also be a previous offender where a FGC found the child to be in need of care and protection. This was severely criticised at the Select Committee stage. This was because of the nature of the FGC, which is informal and encourages children to acknowledge wrong-doing and make a plan for the child's future. At the second reading stage the Bill was amended so that the previous offender definition no longer included instances where the order was made from a decision of a FGC.

This definition too can be illustrated through a hypothetical scenario, again using Manu again as the subject.

\section{Scenario Two:}

For his first serious offence - party to aggravated burglary - the Youth Court, realising Manu has care and protection issues, remits him to the informant. ${ }^{86}$ The Family Court issues a care and protection order for Manu. One year later, Manu is wandering the neighbourhood with Remi. Manu sees an open

82 Criminal Justice Act 2006 (Ireland), ss 52(1) and (2); Children Act 2001 (Ireland).

84 Ibid, s 261.

86 Children Young Persons and Their Families (Youth Courts Jurisdiction and Orders) Amendment Act 2010, s 20 . 
window in an abandoned house and incites Remi, as he is the taller of the two, to climb in the window and start a fire inside the property. While Remi is climbing in the window he is stopped by police. Manu is charged with incitement to attempted arson.

This scenario illustrates that the previous offender definition can be triggered for an inchoate offence, which carries the same penalty as the full offence. ${ }^{87}$ As with scenario one, no consideration is given to Manu's care and protection needs, because the previous offender clause is triggered by an offence carrying a 10 year penalty. The new Act introduces the principle that the underlying causes of the child or young person's offending should be taken into account. ${ }^{88}$ For children, it would seem that the best way to do this is for a care and protection order to be made.

The main criticism of this section is in regards to the implicit changes it makes to the way we view child offenders. In our criminal justice system, when sentencing an adult offender, a previous offence may be an aggravating factor or the absence of a previous offence may be a mitigating factor. The reason previous offending is examined at sentencing is because it gives the sentencing judge some indication of the level of remorse and culpability an individual feels about committing an offence. ${ }^{89}$ A previous offence is also used to determine the likelihood of re-offending and the likely response to a specific sentence or programme. ${ }^{90}$ In changing the jurisdiction of the court for a previously offending child, Parliament is essentially importing additional judgments about the extent of responsibility and remorse a child has for their offending, which imports an additional mental element on a child. This is inconsistent with the principles of the CYPF Act because it focuses on the responsibility of the individual child, rather than on the level of care and protection that child is receiving.

Interestingly though, had Manu himself committed arson as a second offence, he would not have been a previous offender because arson carries a higher penalty. In that case he would have been a serious offender. This again seems to confuse the reason for the labels 'serious' and 'previous' offenders. While it may have simply been Parliament's intention to enable children with a history of offending to have a lower threshold, the effect is that the labels serious offender and previous offender carry different connotations. The use of the term previous offender may also create a labelling effect. This theory holds that offenders will self-identify with the labels used to classify them. ${ }^{91}$ In this case, Manu could view himself as a previous offender which may create a perception that he is a criminal person by nature and cannot change future behaviour.

87 Crimes Act 1961, s 66(1).

88 Children, Young Persons, and Their Families Act 1989, s208(ff).

89 Geoff Hall Sentencing 2007 Reforms in Context (LexisNexis, Wellington, 2007) at 109.

90 Ibid.

91 See Howard Becker Outsiders (Free Press, New York, 1997). 


\section{RECONCILING SECTION 14 WITH PARLIAMENT'S PURPOSE}

This section tries to reconcile Parliament's purpose - as identified in the problem definition with how it was translated in s 14 . The author has created an intervention logic diagram to assist this part. $^{92}$

\section{A An Intervention Logic Approach}

The purpose of the diagram is to illustrate the logic of a policy. ${ }^{93}$ That is, how, by making the policy change, the problem identified by Parliament could be addressed. The first column, policy logic, shows the chain of events which must occur for a new policy initiative to resolve the problem. The second column, assumptions, shows the leaps of faith which are necessary in order to achieve the ultimate goal. The final column, risks, is what could happen if any of the assumptions fail.

The first column shows how this chain of logic might work given the purposes which are identified. Parliament identified the need to target 12 and 13 year old serious and recidivist offenders, this can be summarised as one overall objective of wanting to reduce the number of 12 and 13 year olds who commit crimes and are involved in the court process. This objective is at the top of the policy logic, with 'fewer serious and recidivist offenders' as the sub-goal. At the bottom of the chain, is the Government's policy option: extending the jurisdiction of the Youth Court. The policy logic essentially breaks down the chain of events which are required for the policy option to fulfil the ultimate goal. This chain requires that one or some of the Youth Court's new orders are made and that the orders are implemented effectively. This implementation must then create a change in the behaviour of the child.

92 K Baehler "Intervention Logic: A User's Guide" (2002) Policy Sector 25(3) at 14

93 Ibid. 


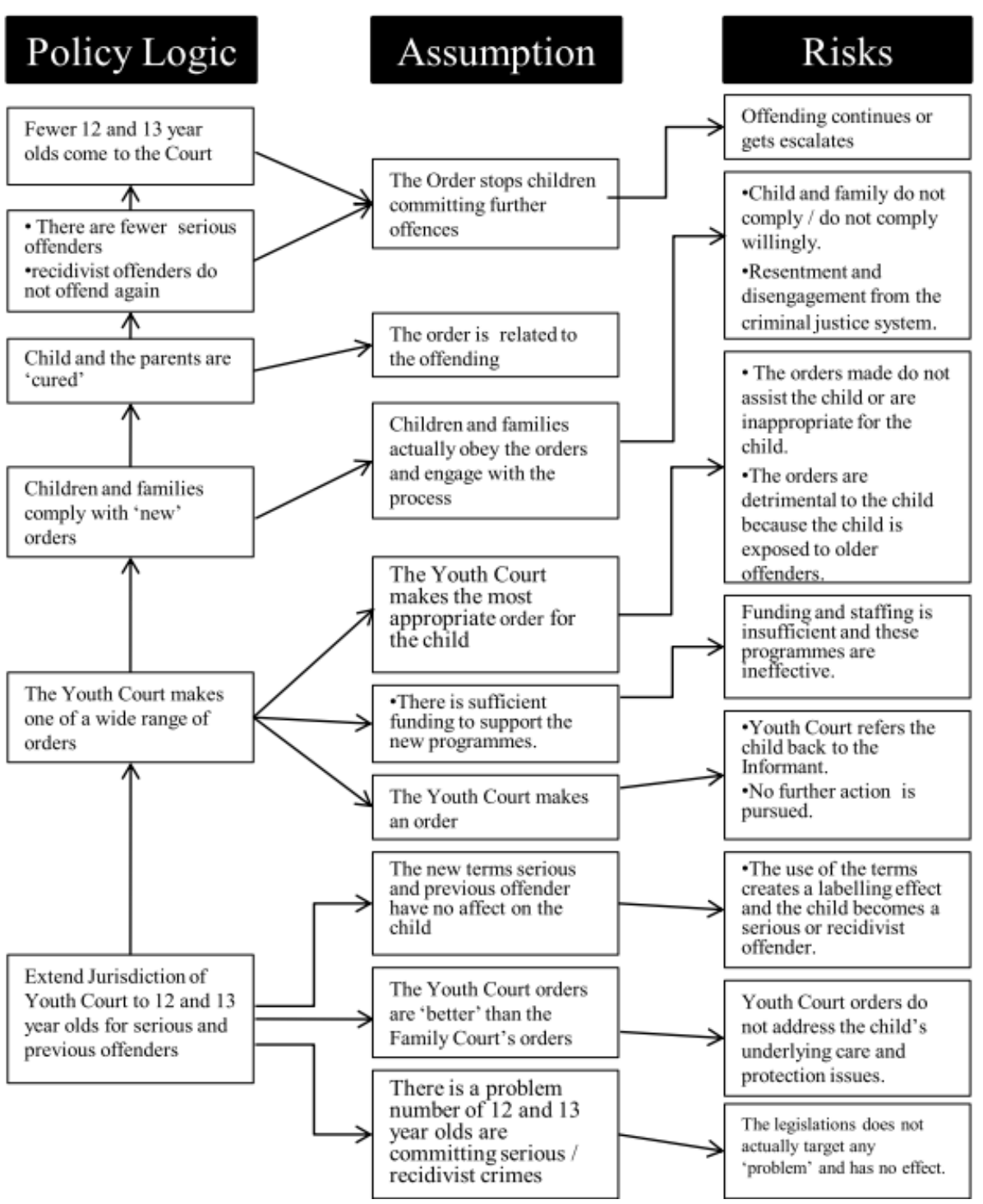

\section{Figure One: Intervention Logic for the Extension of the Youth Court's Jurisdiction}

For each of the steps in this policy logic there are assumptions which are being made. ${ }^{94}$ The number of assumptions identified in this intervention logic highlights the large leaps of faith which

94 Ibid, at 15. 
seem to be employed in relating the problem definition to the actual policy option. The most significant assumptions to note here are: that the orders made by the Youth Court are more effective than those of the Family Court; that the orders are appropriate for the child; and that the orders are an effective cure for the offending.

For each assumption which is made in the chain there are risks which will be incurred if the assumption fails. ${ }^{95}$ At the policy design stage the policy setter would try to mitigate these risks. The main risks are: that the policy is not utilised by the Youth Court; or that the orders are made, but they fail to address child offending. In the event that the order fails to deliver the desired outcome, the risk is the child's problems are compounded as a result of mixing with older offenders and institutionalisation. The problem with the risks identified in this model is that they are not easily remedied.

\section{B Changing Responsibility Along with Penalties}

The United Nations Convention on the Rights of the Child (the Convention) sets out the obligations of states towards their children. ${ }^{96}$ The overarching principle of the Convention is that the "best interests of the child shall be of primary consideration". ${ }^{97}$ This international treaty obligation is a relevant consideration for New Zealand courts. ${ }^{98}$ The CYPF Act gives effect to this through the principle that the welfare of the child is paramount. ${ }^{99}$ However, the effect of the new Act is that this principle does not apply to 12 and 13 year old serious and recidivist offenders.

The United Nations recognises that the age of criminal responsibility is determined according to whether children have moral and psychological competence for their actions, so as to be held to the adult standard of criminal responsibility. ${ }^{100}$ While there is no internationally accepted age of criminal responsibility, the Committee on the Rights of the Child has criticised nations whose minimum age of criminal responsibility is lower than 12 years. ${ }^{101}$ The United Nations Committee has made recommendations that New Zealand raise its minimum age of criminal liability from 10

95 Ibid, at 14 .

96 New Zealand ratified the Convention in 1993.

97 United Nation Convention on the Rights of the Child (opened for signature 20 November 1989, entered into force 2 September 1990), art 3.

98 See Ding v Minister of Immigration (2006) 25 FRNZ 568, at [138]-[164].

99 Children, Young Persons and Their Families Act 1989, s 6.

100 United Nations Standard Minimum Rules for the Administration of Juvenile Justice GA Res 40/33, A/Res/40/33 (1985) at 3.

101 Andrew Becroft "How to turn a Child Offender into an Adult Criminal - In 10 Easy Steps" (Children and the Law International Conference, Prato Italy, 7 September 2009) at 11. 
years. ${ }^{102}$ The minimum age was considered by the Government in 2003 , but no change was made. ${ }^{103}$ The reason for this was because, despite 10 years being the age of criminal responsibility, the treatment of under 14 year olds is different than that of 14 to 17 year olds.

The new Act is moving further away from a system of dealing with children and young people differently. Judge Becroft has posited that the extension of jurisdiction was "contrary to the spirit of the United Nations Convention on the Rights of the Child". ${ }^{104}$ This is because the Convention emphasises a line-in-the-sand approach to the age of responsibility, below which children do not have mental capacity. ${ }^{105}$ The Human Rights Commission in their submission to the Select Committee suggested that opening up 12 and 13 year olds to Youth Court jurisdiction: ${ }^{106}$

... appears to suggest that a child or young person who commits a more serious offence is also more

likely to understand the nature of his or her actions than one who commits a non-serious offence. There

is no logical reason why this should be the case.

Creating additional carve outs from the age of responsibility confuses our understanding of why children and young people are treated differently. It seems Parliament was looking for a short-cut way of offering a wider range of orders for children. By pursuing these orders through moving the jurisdiction, the Government is also implicitly making a statement about the mental capacity of 12 and 13 years olds who commit serious offences.

\section{Evaluation}

The intervention logic model is only one way of formulating a link between the policy option and the policy objective. It is simply intended to illustrate how a causal relationship might work. In reality, the system is infinitely more complex. In order to understand the effect of these changes, evaluation of the policy is vitally important. Any changes made to the youth justice system should be supported by adequate funding to commission independent evaluation of the new policy. In the past, it has been difficult to discern whether initiatives make a tangible difference because of a lack of monitoring and appraisal of new policies. ${ }^{107}$ The government could introduce a requirement that the new policy is independently reviewed. This would help establish whether the policy was affecting the rights of the child or undermining the principles of the CYPF Act.

102 Ministry of Youth Development Five-Year Work Programme 2004 to 2008 (Ministry of Youth Development, Wellington, 2008) at 6-7.

103 Ibid, at 7.

104 Becroft, above n 101, at 10.

105 Ibid.

106 Human Rights Commission "Submission on the Children, Young Persons and their Families (Youth Courts Jurisdiction and Orders) Amendment Bill" at 5.

$107 \mathrm{~J}$ Cameron, J Guest and R Ludbrook, above n 16 at [NT 1.1.06]. 


\section{HOW ELSE COULD THE PURPOSE HAVE BEEN ACHIEVED?}

This section of the paper considers question three: how else could Parliament's purpose have been achieved? Specifically, how could it be achieved without changing the underlying assumptions we make about the level of responsibility of child offenders? As identified in the problem definition section, it seemed implicit that the Family Court was not adequately addressing the needs of serious and recidivist children. It is this author's belief that before implementing a brand new policy the status quo should first be examined. This could have been achieved by giving the Family Court itself a wider range of options for dealing with serious child offenders as well as pumping more resources into the process of dealing with child offenders generally. This paper will examine how the status quo could be improved to provide alternative solutions which could have addressed the dual issues the government identified.

\section{A Powers of the Family Court}

In the lead up to the Bill's passing, it was argued that the range of orders available to the Youth Court would provide a better range of options for dealing with child offenders. ${ }^{108}$ However, this failed to recognise the extensive powers the Family Court already has. Even with the extended range of options available to the Youth Court, the Court does not have the ability to make the Care and Protection Orders which the Family Court can. The Youth Court's powers are prescriptive and time limited. The maximum sentence in a Residential Care Facility is six months; however, Care and Protection Order can be ongoing. Additionally, the Family Court has a much more flexible process and has jurisdiction to use provisions available under many Acts, including: the Adoption Act 1955; the Care of Children Act 2004; the Family Protection Act 1980; and the Domestic Violence Act 1995.109

Care and Protection Orders may be preferable because they address the root cause of the offending, the child's environment. The underlying philosophy is that while still a child, offending should not be attributed to the child, but their wider circumstances. Lawyer Robert Ludbrook, was against the extension of jurisdiction to 12 and 13 year olds because children's offending is so closely connected to their family situation. He argued that Care and Protection orders, made by the Family Court, are a better alternative because they allow the Court to make an assessment of the child's upbringing and home life. ${ }^{110}$ Additionally, Ludbrook thought that 12 and 13 year old offenders would only be in a worse environment if they associated with older offenders in detention facilities.

108 See for example John Key "Key Notes no 25, 2008: A Fresh Start" (28 January 2008) National <www.johnkey.co.nz〉 (16 February 2010) 660 NZPD 8777.

109 Children, Young Persons and Their Families Act 1989, s 158.

110 R Ludbrook "Submission to Social Services Select Committee on Children, Young Persons, and Their Families (Youth Courts Jurisdiction and Orders) Amendment Bill 2009" at 4. 
The Youth Court's submission likewise felt that their orders did not fulfil the needs of 12 and 13 year olds "who by definition will have the most serious care and protection issues, yet the Youth Court will not have the necessary 'ammunition' to deal with the inevitable care and protection issues at the root of the offending."111

However, it must be acknowledged that there are few specialist programmes for repeat and serious child offenders. In the event that the existing powers of the Family Court are inadequate, one simple solution would have been to give the Family Court the new powers of the Youth Court. Because these orders are discretionary the Family Court could simply reserve these orders where they thought the nature of the offence was sufficiently serious. It would not be necessary to specify to the court what a serious offence was. The judge would give consideration to the age of the child when making such an order, so it is likely that the orders would only be available for children at the upper end of the 10-13 year age bracket. These orders would be of further benefit to child offenders if they operated separately from young people and the programmes were only attended by other children. This would mitigate concerns raised in Select Committee submissions that young people would be a bad influence on younger children. ${ }^{112}$ The significance of the change here is that the principle - that the interests of the child are paramount - would continue to be applicable.

Another alternative would be to amend ss 6 and 208 of the CYPF Act so that principles applicable to children follow the child, rather than the court. ${ }^{113}$ The weakness of this option is that the Youth Court would then have to alternate between two sets of principles. This would confuse the mandate of the Youth Court. Additionally, it seems contrary to the recommendation that New Zealand continues to have separate courts for children and young people.

\section{$B$ The Child Offender Process}

In their submission to the Social Services Select Committee, the Police Association argued that the current child offender process is seen by police as "complex, lengthy, and unlikely to deliver an effective response to offending". ${ }^{114}$ It was said that, as a result of the difficulty of the process, police officers tended to err on the side of an informal option for addressing child behaviour, even where that behaviour is quite serious. ${ }^{115}$ This attitude of police, in trying to avoid pursuing further penalties, could be evidenced by the fact that there has been a decrease in the number of FGCs. In

111 Youth Court of New Zealand, above n 25, at 5 .

112 See for example Ludbrook, above n 110.

113 Children, Young Persons, and Their Families Act 1989, s 6.

114 Police Association "Children Young Persons and Their Families (Youth Courts Jurisdiction and Orders) Amendment Bill 2009" at [16]

115 Ibid. 
2008 only 12 in 10,000 of all apprehensions resulted in a FGC compared to a high of 26 in $1997 .{ }^{116}$ Given that offending by children has remained static, this decrease must reflect the fact that fewer serious and recidivist children are engaging with the FGC or Care and Protection system at an early stage.

The Police Association's submission is certainly not the first time a concern has been raised about the child offender process. Maxwell and Robertson's 1995 report, Child Offenders: A Report to the Minister of Justice, Police and Social Welfare, addressed the process for dealing with more serious and recidivist child offenders because they were not being adequately dealt with. ${ }^{117}$ This report prompted the Child Offender Manual, ${ }^{118}$ which outlines the correct way in which key stakeholders - the Police, the youth justice coordinator and the social worker - should fulfil their functions and interact with each other. In 2002 the Ministry of Justice Ministerial Taskforce on youth offending produced the Youth Offending Strategy. ${ }^{119}$ This Taskforce conducted a systematic review of the youth offender process. It especially identified serious child offenders as needing increased attention.

The Youth Offending Strategy featured proposals directed towards Youth Aid officers and youth justice coordinators, who must be properly supported, and established youth offending teams to coordinate service delivery at a local level. All of which requires better inter-agency cooperation. ${ }^{120}$ One specific area of concern is the availability of specially trained Youth Aid officers and youth advocates in the provinces. It is more likely that these areas need greater staffing support so that they have a sufficient understanding of the child offender system. The fact that the Police Association made a submission which effectively stated police officers are still not able to engage with the FGC process indicates that the recommendations of the Youth Offending Strategy have not been sufficiently implemented. This further suggests that the recommendations specific to child offenders should be identified and made a priority.

Some policies included in the new Act have their origin in the Youth Offending Strategy. However, extending the jurisdiction of the Youth Court to include 12 and 13 year olds was not one of these recommendations. Improving the child offender process in the manner envisaged by the Youth Offending Strategy would require increased funding for additional personnel to work with these children. The fact that serious and recidivist child offenders have been dealt with in the new

116 Ministry of Justice, above n 35, at 16.

117 Maxwell and Robertson, above n 79.

118 P Boshier, J Moore and S Hale, above n 19.

119 Ministry of Justice and Ministry of Social Development Youth Offending Strategy: Preventing and Reducing Offending and Reoffending by Children and Young People (Ministry of Justice and the Ministry of Social Development, Wellington, 2002).

120 Ibid, at 42 . 
Act by equating them with young people, rather than addressing the underlying causes of problems with Family Court orders and implementing the Youth Offending Strategy is illustrative of populist politics. The policy ultimately implemented is media-grabbing and unlike the initiatives suggested in the Youth Offending Strategy, requires little ongoing investment.

\section{CONCLUSION}

This paper addressed three overarching questions. First, it found the purpose of s 14 was to address serious child offenders and provide a greater range of orders for dealing with these children. However, Parliament's problem definition does not easily reconcile itself with recognised problems within the youth justice system. The lack of qualitative basis for this policy, combined with the Bill being passed in urgency, indicates that s 14 was largely motivated by politics and not an output focussed policy model. Secondly, it was found that, in any event, the extension of the jurisdiction of the Youth Court to children is an ineffective way of addressing child offending. Section 14 is arbitrary in its classification of serious and previous offenders and does not easily reconcile itself with the policy problem identified. Instead, s 14 created the unintended consequence of changing the underlying principles of the CYPF Act. In changing the way these children are dealt with New Zealand risks becoming more punitive. This takes New Zealand further away from our international obligations under the Convention. Thirdly, it was argued that changes could have been made to the status quo which would have better addressed problems facing serious and recidivist child offenders. The CYPF Act was heralded internationally as a model for addressing children and young people. However, to benefit from this model, the principles of the CYPF Act must be adhered to. Moving children to the Youth Court is a band-aid solution which avoids having to invest resources to enable FGCs to work effectively. This paper argues that only policies which truly invest in and strengthen these principles will deliver effective, long-term outcomes for child offenders. 


\section{APPENDIX A}

Table showing list of offences in the Crimes Act 1961 where the penalty is at least 14 years.

\begin{tabular}{|c|c|}
\hline 73 & Treason \\
\hline 78 & Espionage \\
\hline 92 & Piracy \\
\hline 98 & Dealing in slaves \\
\hline 98AA & $\begin{array}{l}\text { Dealing in people under } 18 \text { for sexual exploitation, removal of body part, or } \\
\text { engagement in forced labour }\end{array}$ \\
\hline $98 \mathrm{C}$ & Smuggling migrants \\
\hline 98D & Trafficking in people by means of coercion or deception \\
\hline 109 & Punishment of perjury \\
\hline 115 & Conspiring to bring false accusation \\
\hline 128 & Sexual violation \\
\hline $142 \mathrm{~A}$ & Compelling indecent act with animal \\
\hline 172 & Punishment of Murder \\
\hline 173 & Attempt to Murder \\
\hline 177 & Punishment of Manslaughter \\
\hline 179 & Aiding and Abetting suicide \\
\hline 183 & Procuring abortion by any means \\
\hline 188 & Wounding with intent \\
\hline 191 & Aggravated wounding or injury \\
\hline 194 & Assault on a child, or by a male on female \\
\hline 198 & Discharging firearm or doing dangerous act with intent \\
\hline $198 \mathrm{~A}$ & Using any firearm against law enforcement officer etc. \\
\hline 199 & Acid throwing \\
\hline 200 & Poisoning with intent \\
\hline 201 & Infecting with disease \\
\hline
\end{tabular}




\begin{tabular}{|l|l|}
\hline 208 & Abduction for purposes of marriage or sexual connection \\
\hline 209 & Kidnapping \\
\hline 232 & Aggravated burglary \\
\hline 235 & Aggravated robbery \\
\hline 236 & Assault with intent to rob \\
\hline 238 & Punishment of blackmail \\
\hline 239 & Demanding with intent to steal, etc \\
\hline 267 & Arson \\
\hline 270 & Endangering transport \\
\hline
\end{tabular}




\section{APPENDIX B}

Table showing list of Offences listed in Crimes Act 1961 with penalty of at least 10 years but less than 14 years.

\begin{tabular}{|c|c|}
\hline 77 & Inciting to Mutiny \\
\hline 79 & Sabotage \\
\hline 96 & Conspiring to Commit Piracy \\
\hline $98 \mathrm{~A}$ & Participation in an Organised Criminal Group \\
\hline 129 & Attempted sexual violation and assault with intent to commit sexual violation \\
\hline 130 & Incest \\
\hline 138 & Sexual Exploitation of a Person with Significant Impairment \\
\hline 174 & Counselling or attempting to procure murder \\
\hline 175 & Conspiracy to Murder \\
\hline 189 & Injuring with Intent \\
\hline 198B & Commission of Crime with Firearm \\
\hline 204 & Impeding Rescue \\
\hline 231 & Burglary \\
\hline 234 & Robbery \\
\hline 250 & Damaging or Interfering with Computer System \\
\hline 256 & Forgery \\
\hline 257 & Using Forged Documents \\
\hline 258 & $\begin{array}{l}\text { Altering, concealing, destroying, or reproducing document with intent to } \\
\text { deceive }\end{array}$ \\
\hline 259 & Using altered or reproduced document with intent to deceive \\
\hline 260 & False Accounting \\
\hline 261 & Counterfeiting Public Seals \\
\hline 264 & Paper or instruments of forgery \\
\hline 266 & Offences involving coinage \\
\hline
\end{tabular}




\begin{tabular}{|l|l|}
\hline 268 & Attempted Arson \\
\hline 269 & Intentional Damage \\
\hline $298 \mathrm{~A}$ & Causing Disease or Sickness in Animals \\
\hline $298 \mathrm{~B}$ & Contaminating food, crops, water, or other products \\
\hline
\end{tabular}


